\title{
Changes in distribution, relative abundance, and species composition of large whales around South Georgia from opportunistic sightings: 1992 to 2011
}

\author{
Jessica Richardson ${ }^{1, *}$, Andrew G. Wood ${ }^{2}$, Alison Neil ${ }^{3}$, Doug Nowacek ${ }^{1,4}$, \\ Michael Moore ${ }^{5}$ \\ ${ }^{1}$ Nicholas School of the Environment, and ${ }^{4}$ Pratt School of Engineering, Duke University Marine Laboratory, \\ Duke University, 135 Duke Marine Lab Road, Beaufort, North Carolina 28516-9721, USA \\ ${ }^{2}$ British Antarctic Survey, High Cross, Madingley Road, Cambridge CB3 0ET, UK \\ ${ }^{3}$ South Georgia Heritage Trust, Verdant Works, West Henderson's Wynd, Dundee DD15BT, UK \\ ${ }^{5}$ Biology Department, Woods Hole Oceanographic Institution, Woods Hole, Massachusetts 02543, USA
}

\begin{abstract}
To examine the general population trends of large whales in South Georgia waters, 2 opportunistic data sets of sightings of large whales from 1991 to 2010 around South Georgia were analyzed: the South Georgia Museum log of whale sightings and the British Antarctic Survey whale sighting reports from the Bird Island research station. Bird Island abuts the northwest tip of South Georgia. The 4 most reported species in both data sets were southern right whale Eubalaena australis, humpback whale Megaptera novaeangliae, minke whale Balaenoptera bonaerensis, and killer whale Orcinus orca. These totally independent data sets showed comparable changes in abundance through time; thus, despite a lack of sighting effort records, inferences could be drawn about changes in relative abundance. The number of reported sightings per $5 \mathrm{yr}$ period from both data sets increased from the 1991 to 1995 period through the 2001 to 2005 period and has since decreased. Species composition of reported sightings has changed over time; southern right whales have become the most sighted species in both data sets, with a peak of reported sightings in the 2001 to 2005 period. Sightings were concentrated around Shag Rocks, at the northwest tip of South Georgia, and along the north/east coastlines of South Georgia; sightings in the bays around South Georgia have increased over time. In an area such as the Antarctic, which poses many difficulties when conducting research, opportunistic data sources such as these, although not ideal, can become invaluable, since such information would otherwise be unattainable.
\end{abstract}

KEY WORDS: South Georgia $\cdot$ Whale $\cdot$ Whaling $\cdot$ Antarctic

\section{INTRODUCTION}

South Georgia waters were perhaps the most whale-dense habitat on the planet 100 yr ago; over a $7 \mathrm{yr}$ period from 1923 to 1930, harvests of 1 to $>1000$ fin whales Balaenoptera physalus and 1 to $>990$ blue whales B. musculus were reported from single 261 square nautical mile $\left(675.9 \mathrm{~km}^{2}\right)$ grid cells near the island (Fig. 1) (Kemp \& Bennett 1932). The South Georgia area is known to be an important feeding ground for large whales due to the high density of
Antarctic krill Euphausia superba there (Reid et al. 2000, Hedley et al. 2001, Rowntree et al. 2001, Atkinson et al. 2004, Leaper et al. 2006, Murphy et al. 2007, Valenzuela et al. 2009, International Whaling Commission 2010, 2011a). These waters are characterized by high biomass and productivity of phytoplankton, zooplankton, and vertebrate predators. The causes of this productivity remain unclear, despite studies dating back over a century, but commercial fisheries have exploited the abundant resources since the late 1700s (Atkinson et al. 2001). The most notable ex- 


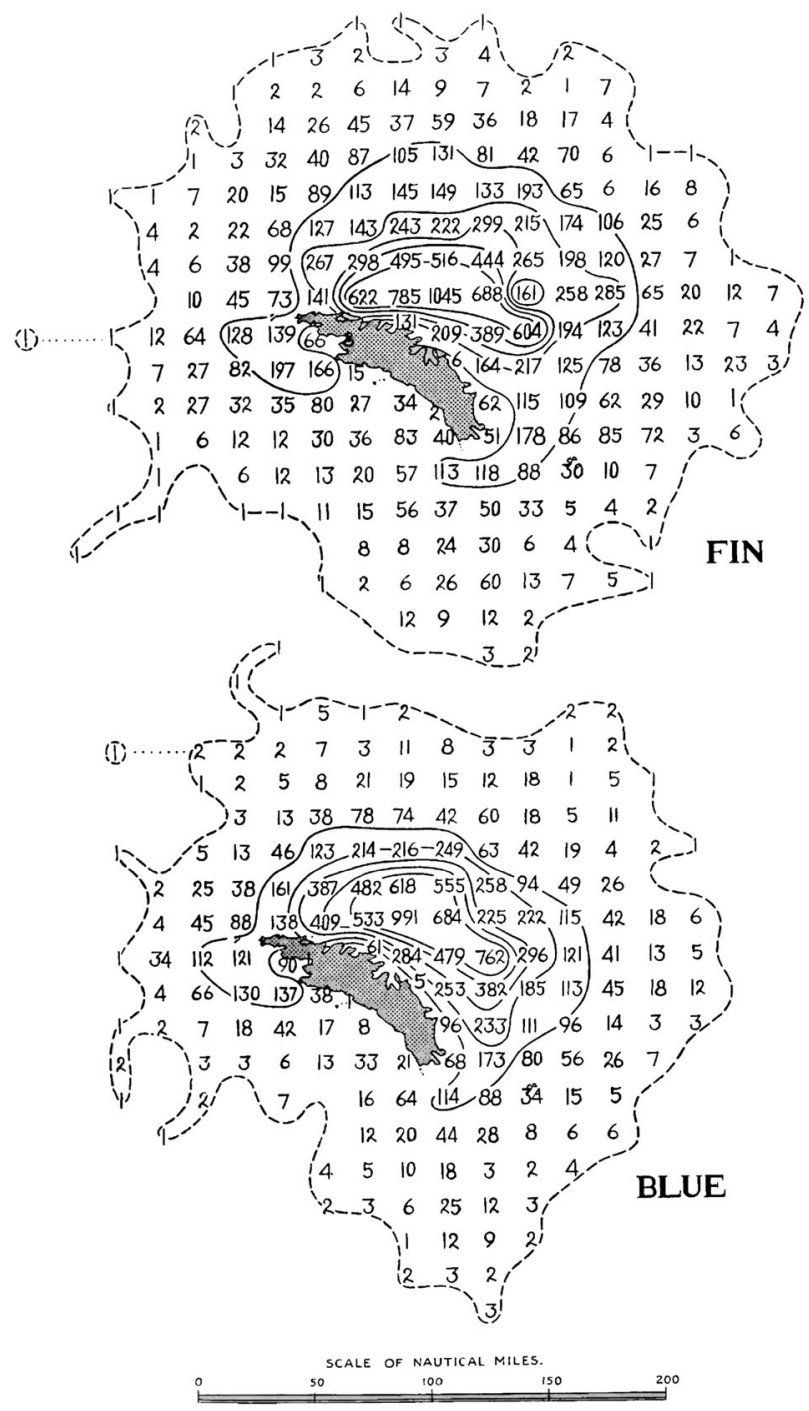

Fig. 1. Balaenoptera physalus and B. musculus. Distribution of fin and blue whales per 261 square nautical mile (675.9 km) grid cells around South Georgia (shaded area), based on all recorded positions of capture between 1923 and 1930. Figure courtesy of Kemp \& Bennett (1932)

ploitation in South Georgia waters is that of the populations of large whales. In 1903, Norwegian whaler C. A. Larsen noted 'they are very big whales and I saw them in the hundreds and thousands' (Tønnessen \& Johnsen 1982, p. 160). A year later Larsen returned to establish the first whaling station on South Georgia. After his highly successful first year, the desire to obtain whaling permits and establish stations on South Georgia intensified; by the 1912 to 1913 season, 6 stations were operating on the island and South Georgia had become known as the southern capital of whaling (Allen 1980, Tønnessen \& Johnsen 1982, British Antarctic Survey 1999).
Historically, whaling is characterized by a progression from more valuable or more easily caught species to less attractive species as stocks of the original targets became depleted (Allen 1980). Antarctic whaling is no exception. Catches throughout the Antarctic can be divided into 5 periods: humpback whales Megaptera novaeangliae from 1904 to 1912, blue whales from 1913 to 1937, fin whales from 1937 to 1965, sei whales Balaenoptera borealis from 1965 to 1975 , and minke whales $B$. bonaerensis ${ }^{1}$ from 1975 to present (Tønnessen \& Johnsen 1982). While other species were caught during each period, the species mentioned was the targeted species and represented the bulk of the catch. Southern right whale Eubalaena australis stocks were depleted in the southern hemisphere by the mid-19th century, before whaling stations were established on South Georgia, so they comprised only a minimal portion of catches (Allen 1980).

The $61 \mathrm{yr}$ period of whaling in the waters of South Georgia (1904 to 1965) spanned the first 3 'periods' of Antarctic whaling: humpback whale, blue whale, and fin whale. Catches at South Georgia included: blue, fin, sei, humpback, minke, southern right, and sperm Physeter macrocephalus whales, most of which were depleted to $<10 \%$ of their original stock size (Tønnessen \& Johnsen 1982, Best 1993, Clapham \& Baker 2009). When whaling ceased in South Georgia in 1965, a reported 175250 whales had been processed at the land-based whaling stations alone since 1904 (Committee for Whaling Statistics 1942, 1951, 1953, 1954, 1955, 1956, 1957, 1958, 1959, 1960, 1961, 1962, 1963, 1964a,b, 1965, 1966, Tønnessen \& Johnsen 1982, Moore et al. 1999); in all, over 2 million whales were taken in the Antarctic between 1900 and 2005 (Clapham \& Baker 2009).

Decades later, sightings are still relatively rare, and little is known about the populations that utilize South Georgia waters as feeding grounds (Moore et al. 1999, Reid et al. 2000, Hedley et al. 2001, RossiSantos et al. 2007). Southern right whales and humpback whales that breed off the coast of South America (Peninsula Valdés, Argentina, and Abrolhos Bank, Brazil, respectively) have been traced to South Georgia feeding grounds; however, these are limited cases representing only a handful of individual whales (Best et al. 1993, Moore et al. 1999, Rowntree et al. 2001, Stevick et al. 2006, Zerbini et al. 2006, Engel \& Martin 2009, Valenzuela et al. 2009). This

1Minke whales recorded may also be of the species B. acutorostrata 
general lack of knowledge stems from the inherent difficulty associated with studying cetaceans in the Antarctic; research in the area is quite costly, and sighting conditions are often unfavorable. For these reasons, opportunistic data may be useful in lieu of quantitative line transect studies to examine broad trends in area usage by populations of large whales over time. Independent, continuous historical data sets are kept of opportunistic sightings around South Georgia $\left(55^{\circ} \mathrm{S}, 36^{\circ} \mathrm{W}\right)$ by the South Georgia Museum and the British Antarctic Survey station at Bird Island $\left(54.017^{\circ} \mathrm{S}, 38.05^{\circ} \mathrm{W}\right)$. These data sources have little to no direct costs and, despite a lack of sighting effort data and study design, may illustrate general trends in the use of South Georgia waters by species of large whales. This paper presents findings from the analysis of these 2 opportunistic data sets.

\section{MATERIALS AND METHODS}

\section{Museum log reports}

The South Georgia Museum in Grytviken was founded in 1992 by Nigel Bonner. Vessels of various types (e.g. fishery patrol, military, recreational, commercial fishing, cruise, research, etc.) that travel to South Georgia waters generally stop at Grytviken to clear into the port of entry and, in so doing, often visit the museum where they are encouraged to record any whale sightings during their passage in the museum's log book. This written log has been kept at the museum since December 1995; sightings from the logs of yachts, commercial cruise ships, and British Navy ships since 1992 have been appended to this written log, resulting in almost 2 decades of continuous sighting records. Sighting entries vary in detail and completeness but include some or all of the following information: sighting date, species, number of animals, observing vessel, vessel type, position coordinates of the sighting, description of the sighting location, and further comments about the sightings. Sightings are logged as sighting events; each event can include one or many individuals. Observers range from cruise passengers to seamen to military officials to naturalists, so the accuracy of species identification in this data set is often less than that achieved by specifically trained marine mammal observers. For the purpose of this study all reports that indicated any uncertainty regarding species identification were classified as 'unidentified'. Due to the difficulty of identifying beaked whales (Family Ziphiidae) to the species level, all beaked whales were grouped into a single category.
Reported sightings were georeferenced using GoogleEarth (earth.google.com) and ArcGIS 10 (ESRI) based upon coordinates provided and/or location descriptions. Due to the variety in available data, some point locations are exact, as they are from given coordinates, while others are more arbitrarily placed, based on the given description of the sighting location (an interactive map of these sightings can be found at www.sght.org/sites/default/files/South \% 20 Georgia.html). Entries with no location information or vague location descriptions were disregarded for spatial analysis. Sightings were organized by season, defined as periods extending from August to July (e.g. sightings from August 1991 through July 1992 were classified as the 1991 season). For analysis purposes, sightings were separated into 4 bins, each representing 5 seasons of data (1991 to 1995, 1996 to 2000, 2001 to 2005, and 2006 to 2010). Species composition, sighting locations, and overall sighting abundance were analyzed for variation over time.

\section{Bird Island data}

Bird Island is a small island $(4.8 \mathrm{~km}$ long and up to $800 \mathrm{~m}$ wide) that lies off the northwestern tip of South Georgia Island (see Fig. 2). The British Antarctic Survey (BAS) has occupied a research base there every summer since 1975/1976 and year-round since September 1983. There are typically 4 employees on station throughout the winter (May to October), with up to 10 during the summer (November to April). Although the BAS scientific research at Bird Island focuses on seabirds and seals, incidental sightings of cetaceans are recorded in the unpublished annual report (Bird and Mammal Report, Bird Island, British Antarctic Survey). Sighting records in these reports are less descriptive, including sighting date and a written description of the sighting that notes the species seen, number of animals, and other comments on the sighting. Annual reports are archived by the BAS and accessible on request; we acquired reports from the 1991 season through the most current report (2010 season) (British Antarctic Survey Archives Service, Ref. No AD6/2BI, years 1991 to 2009; copyright NERC/BAS) for comparison with the museum records. BAS observers are typically trained, professional field biologists, albeit not necessarily trained in identification of large whales. Any uncertainty concerning species identification was recorded as 'unidentified'.

Since location information was absent or vague in many cases in the Bird Island records, these data 
were not georeferenced or analyzed for spatial trends. Sightings were organized by season and separated into temporal bins as described for the museum data. Species composition and overall sighting abundance were analyzed for variation over time. Trends in museum data were compared with those of the Bird Island data.

\section{RESULTS}

The 4 most reported species for the South Georgia Museum log and BAS Bird Island station records were southern right whale, humpback whale, minke whale, and killer whale Orcinus orca. Other reported species include beaked whales (Family Ziphiidae), blue whale, fin whale, hourglass dolphin Lagenorhynchus cruciger, long-finned pilot whale Globi- cephala melas, sei whale, and sperm whale (Fig. 2). The number of reported sightings per $5 \mathrm{yr}$ period in both data sets increased from the 1991 to 1995 through the 2001 to 2005 period and has since decreased (Figs. 2 to 4). Species composition of reported sightings has changed over time. Southern right whales have become the most sighted species for both data sets, with a peak of reported sightings during the 2001 to 2005 period (Fig. 4a,b). Other species have varied in relative sighting frequency over time and between data sets (Fig. 4a,b) - with the exception of blue and fin whales, sightings of which remained scarce. Sightings were concentrated around Shag Rocks, at the northwest tip of South Georgia, and along the north/east coastlines of South Georgia (Fig. 2). Sightings in the bays around South Georgia have increased over time; southern right, minke, and humpback whales were reported in Cumberland Bay
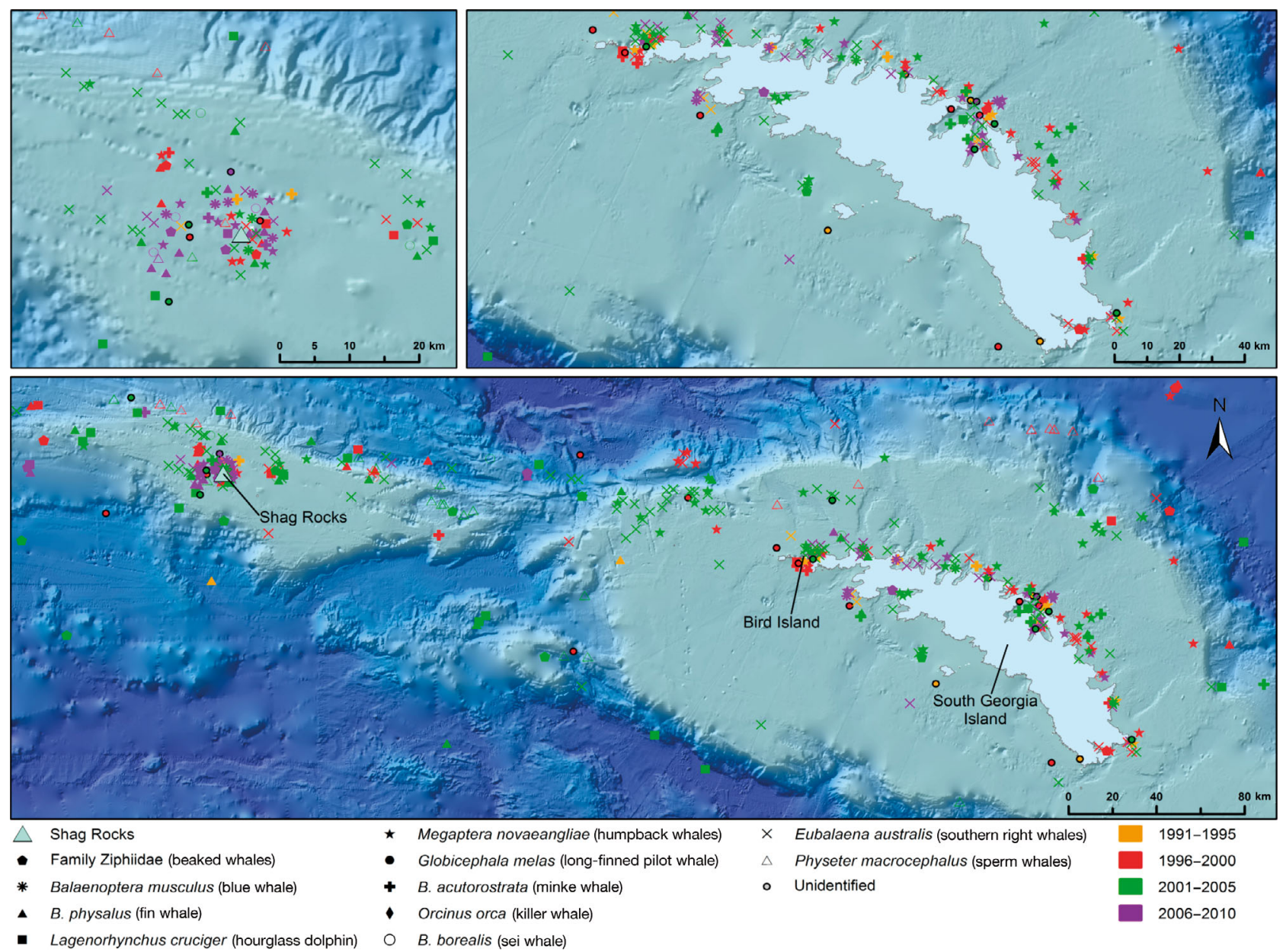

Fig. 2. Whale sightings around South Georgia Island and Shag Rocks by season from 1991 to 2010. Species are denoted by symbols; time periods are denoted by color. Each symbol represents a single sighting event that may include one or many individuals. Bathymetric base map courtesy of Fretwell et al. (2009). Upper panels are higher magnification of western and eastern areas of the lower panel, respectively 


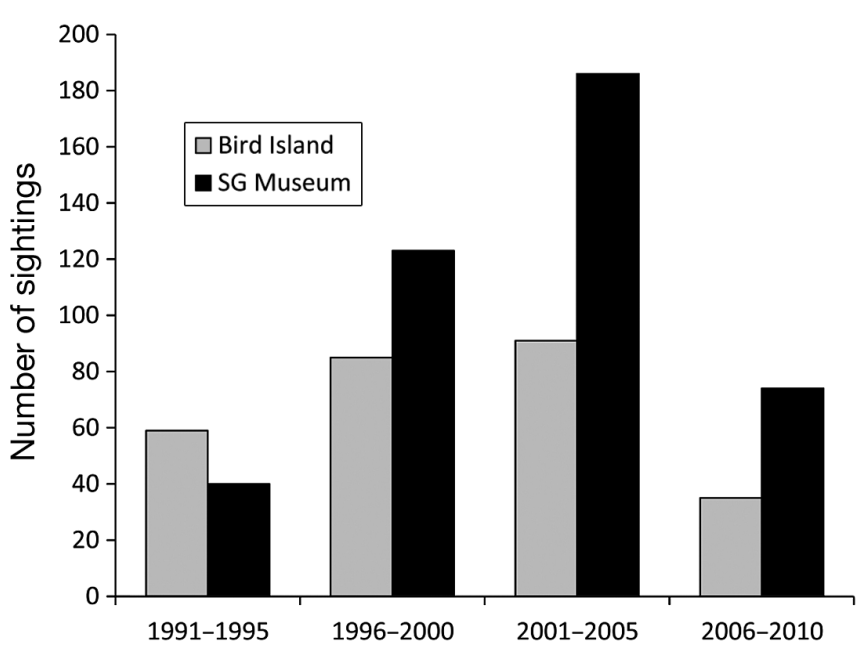

Fig. 3. Total number of sightings of the 4 predominant whale species-Eubalaena australis (southern right), Megaptera novaeangliae (humpback), Balaenoptera bonaerensis (minke), and Orcinus orca (killer) - plus unidentified sightings in four 5 yr periods for Bird Island and South Georgia

(SG) Museum on multiple occasions in the past decade, while there were no reported sightings of minke whales and very few of humpback or southern right whales there in the previous decade (Fig. 2).

\section{DISCUSSION}

Whale sighting records from South Georgia are a useful data source to illustrate general trends in the use of the area by populations of large whales. It is important to note that these data are opportunistic and thus are accompanied by some shortcomings. There is no way to correct for effort with these data sets, and species identifications may not always be accurate. Sighting abundance increased in both the BAS Bird Island Station log and the South Georgia Museum log from 1991 through 2005. Since these data sets are independent of one another - collected in different locations with different methods by different individuals - this change in sighting abundance must be effort independent to a significant degree. Thus, despite some limitations, we can still draw the following conclusions from the data: sightings of large whales have become more abundant around South Georgia since the 1990s, some species are beginning to reappear in bays around the island where sightings had previously been rare, and southern right whales have become the most frequently sighted species in the past decade.

The relative increase, and then decrease, in abundance seen in both data sets may be a result of population growth since the cessation of whaling, coupled with distribution shifts driven by environmental change, given that whale abundance around South Georgia has been known to fluctuate dependent on alterations in the environment (Kemp \& Bennett 1932, Tynan 1998, Murphy et al. 2007 , Forcada et al. 2008), e.g. fluctuations in whale abundance have been shown to correspond with changes in krill density

Fig. 4. Number of sightings for each of the 4 predominant whale species - Eubalaena australis (southern right), Megaptera novaeangliae (humpback), Balaenoptera bonaerensis (minke), and Orcinus orca (killer) - and unidentified sightings in four 5 yr periods for (a) Bird Island and (b) South Georgia Museum 
and abundance in the area (Tynan 1998, Reid et al. 2000, Leaper et al. 2006, Murphy et al. 2007, International Whaling Commission 2011a). Significant rates of increase in all monitored stocks of southern right whale (Best 1990, 1993, Payne et al. 1990, Bannister 2001, International Whaling Commission 2001), as well as humpback whale stocks, have been reported for the southern hemisphere (Paterson \& Paterson 1989, Bryden et al. 1990, Katona \& Beard 1990, Bannister 1994, International Whaling Commission 2004, 2005, 2006, 2007, 2011b). The decrease in number of sightings in the last $5 \mathrm{yr}$ period up to 2010 - for the South Georgia Museum data - may also be the result of staff changes at the museum and aboard vessels, which may have altered the attention paid to and/or awareness of the whale sighting log.

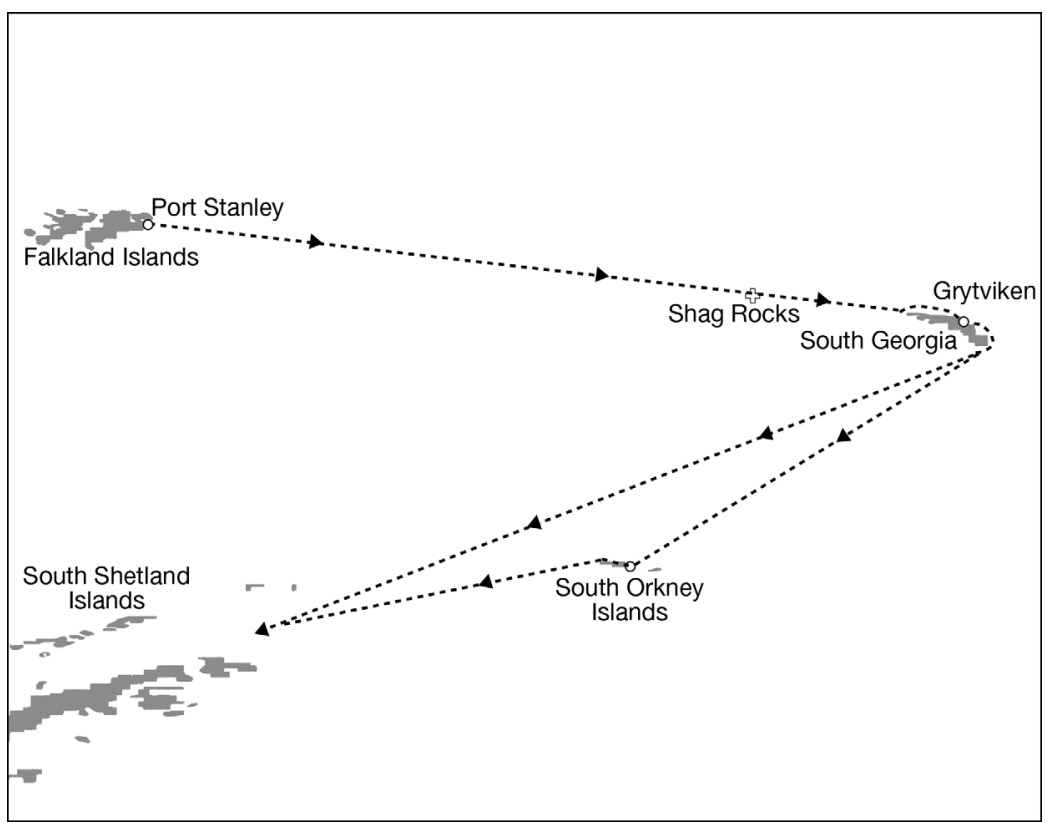

Fig. 5. Typical route of cruise ships visiting South Georgia
Whales have been more frequently reported within the bays along the South Georgia shoreline in the past decade than in the previous decade. At the onset of whaling, there was such an abundance of whales in the bay that boats could tow in 4 to 7 whales daily, limited in their catch by amount of daylight and processing time (Tønnessen \& Johnsen 1982). During the South Georgia whaling era, whales were predominantly caught within 10 to 40 nautical miles of the shore (Mackintosh et al. 1929). Decades after the decimation of these near-shore populations of whales ended, individuals may finally be utilizing these bays again. Sightings are also concentrated around Shag Rocks as previously recorded by research cruises (e.g. Moore et al. 1999), the northwestern tip of South Georgia, and along the north/east shorelines of South Georgia (also reported by Širovic et al. 2006). The concentration of these sightings is most certainly biased by the tracks of the ships-generally tourist vessels coming from the Falkland Islands via Shag Rocks to South Georgia and around the north/east shores of South Georgia, often continuing on to the South Orkney Islands or South Shetland Islands (Fig. 5).

Southern right whales have become the most frequently sighted species in the past decade, in both the BAS Bird Island Station and the South Georgia Museum log records, while sightings of blue and fin whales remained scarce. Because both information sources illustrate the same change in species composition of sightings, this has to be at least some- what independent of changes in effort. Further, changes in relative abundance are unlikely to be a result of effort variation as the likelihood of sighting one species versus another should be independent of effort. Recent studies agree with this finding, noting southern right whales as being the most frequently sighted species during research cruises in the South Georgia area (Moore et al. 1999, Reid et al. 2000). Other previous studies commonly reported sightings of southern right whales and humpback whales near South Georgia and few sightings of minke whales, blue whales, and fin whales in the area with respect to number of sightings throughout the Antarctic (Reid et al. 2000, Reilly et al. 2004, Šrovic et al. 2006).

In this instance, opportunistic sighting records allowed us to determine general trends in the abundance, distribution, and species composition of the populations of large whales utilizing waters around South Georgia. This data source has been continuous for 2 decades and costs little or nothing to use, as sightings are recorded, logged, and maintained as part of various other funded activities. Similar studies have utilized ships of opportunity to conduct effortbased surveys when chartering a vessel for focused surveys was not an option (e.g. Williams et al. 2006). In an area where many difficulties are associated with conducting research, such as the Antarctic, opportunistic data sources or ships of opportunity such as these, although not ideal, can be invaluable, due to the lack of alternative sources. 


\section{CONCLUSIONS}

Large whale species that were depleted during the whaling era at South Georgia may be recovering and have returned to the area - some species more than others. Southern right whales and humpback whales are more frequently sighted, while blue and fin whales are still scarcely seen in the area. These sighting frequencies agree with previous studies of the area. However, better, more quantitative surveys are urgently needed around South Georgia to discover more about these populations and their use of these waters. Due to the costs and difficulties associated with focused surveys in the Antarctic, a potential alternative could be the use of opportunistic vessels to conduct surveys. For example, trained marine mammal observers could be placed on cruise ships to get a more robust, effort-based data set of sightings, or organized tourist group effort-based surveys could be conducted during cruises where tourists work with naturalists to keep an effort-based log of sightings. Opportunistic data and vessels may result in important findings that can shed more light upon the use of feeding grounds around South Georgia by whale populations and help motivate funding for future research surveys in the area.

Acknowledgements. We thank Ellen Bazeley-White of the British Antarctic Survey Archives for providing sighting data from archived reports from Bird Island; Elsa Davidson and Katie Murray of the South Georgia Heritage Trust, who helped acquire information; Richard McKee, Pat Lurcock, and Sarah Lurcock of the South Georgia Island Government, who contributed information about vessel and visitor statistics; British Antarctic Survey observers on Bird Island, who contributed to the sighting records; numerous observers on various vessels contributed to the museum log database. Carl Spielvogel assisted with museum log transcription. Peter Fretwell, Alex Tate, Tara Deen, and Mark Belchier created the bathymetric grid used as a base map. We thank Peter Corkeron for his constructive review of the data. Research was funded by the Woods Hole Oceanographic Institution/Duke University Fellowship.

\section{LITERATURE CITED}

Allen KR (1980) Conservation and management of whales. University of Washington Press, Seattle, WA

Atkinson A, Whitehouse MJ, Priddle J, Cripps GC, Ward P, Brandon MA (2001) South Georgia, Antarctica: a productive, cold water, pelagic ecosystem. Mar Ecol Prog Ser 216:279-308

Atkinson A, Siegel V, Pakhomov E, Rothery P (2004) Longterm decline in krill stock and increase in salps within the Southern Ocean. Nature 432:100-103

Bannister J (1994) Continued increase in humpback whales off Western Australia. Rep Int Whal Comm 44:309-310

Bannister J (2001) Status of southern right whales (Eubalaena australis) off Australia. J Cetacean Res Manag Spec Issue 2:103-110

$>$ Best PB (1990) Trends in the inshore right whale population off South Africa, 1969-1987. Mar Mamm Sci 6:93-108

> Best PB (1993) Increase rates in severely depleted stocks of baleen whales. ICES J Mar Sci 50:169-186

Best PB, Payne R, Rowntree V, Palazzo JT, Both MDC (1993) Long-range movements of South Atlantic right whales (Eubalaena australis). Mar Mamm Sci 9:227-234

British Antarctic Survey (1999) Environmental management plan for South Georgia. British Antarctic Survey, Cambridge

Bryden M, Kirkwood G, Slade R (1990) Humpback whales, area V. An increase in numbers off Australia's east coast. In: Kerry KR, Hempel G (eds) Antarctic ecosystems: ecological change and conservation. Springer-Verlag, Berlin, p 271-277

Clapham PJ, Baker CS (2009) Whaling, modern. In: Perrin WF, Würsig BG, Thewissen JGM (eds) Encyclopedia of marine mammals. Academic Press, San Diego, CA, p 1239-1243

Committee for Whaling Statistics (1942) International whaling statistics - xvi. The Committee for Whaling Statistics, International Whaling Commission, Oslo

Committee for Whaling Statistics (1951) International whaling statistics - xxvii. The Committee for Whaling Statistics, International Whaling Commission, Oslo

Committee for Whaling Statistics (1953) International whaling statistics - xxix. The Committee for Whaling Statistics, International Whaling Commission, Oslo

Committee for Whaling Statistics (1954) International whaling statistics - xxxi. The Committee for Whaling Statistics, International Whaling Commission, Oslo

Committee for Whaling Statistics (1955) International whaling statistics - xxxiii. The Committee for Whaling Statistics, International Whaling Commission, Oslo

Committee for Whaling Statistics (1956) International whaling statistics - xxxv. The Committee for Whaling Statistics, International Whaling Commission, Oslo

Committee for Whaling Statistics (1957) International whaling statistics - xxxvii. The Committee for Whaling Statistics, International Whaling Commission, Oslo

Committee for Whaling Statistics (1958) International whaling statistics - xxxix. The Committee for Whaling Statistics, International Whaling Commission, Oslo

Committee for Whaling Statistics (1959) International whaling statistics - xli. The Committee for Whaling Statistics, International Whaling Commission, Oslo

Committee for Whaling Statistics (1960) International whaling statistics - xliii. The Committee for Whaling Statistics, International Whaling Commission, Oslo

Committee for Whaling Statistics (1961) International whaling statistics - xlv. The Committee for Whaling Statistics, International Whaling Commission, Oslo

Committee for Whaling Statistics (1962) International whaling statistics - xlvii. The Committee for Whaling Statistics, International Whaling Commission, Oslo

Committee for Whaling Statistics (1963) International whaling statistics - xlix. The Committee for Whaling Statistics, International Whaling Commission, Oslo

Committee for Whaling Statistics (1964a) International whaling statistics - li. The Committee for Whaling Statistics, International Whaling Commission, Oslo 
Committee for Whaling Statistics (1964b) International whaling statistics - liii. The Committee for Whaling Statistics, International Whaling Commission, Oslo

Committee for Whaling Statistics (1965) International whaling statistics - lv. The Committee for Whaling Statistics, International Whaling Commission, Oslo

Committee for Whaling Statistics (1966) International whaling statistics - lvii. The Committee for Whaling Statistics, International Whaling Commission, Oslo

Engel MH, Martin AR (2009) Feeding grounds of the western South Atlantic humpback whale population. Mar Mamm Sci 25:964-969

Forcada J, Trathan PN, Murphy EJ (2008) Life history buffering in Antarctic mammals and birds against changing patterns of climate and environmental variation. Glob Change Biol 14:2473-2488

Fretwell PT, Tate AJ, Deen TJ, Belchier M (2009) Compilation of a new bathymetric dataset of South Georgia. Antarct Sci 21:171-174

Hedley S, Reilly S, Borberg J, Holland R and others (2001) Modeling whale distribution: a preliminary analysis of data collected on the CCAMLR-IWC krill synoptic survey, 2000. International Whaling Commission Scientific Committee, Cambridge. www.ruwpa.st-and.ac.uk/ Spatial\%20Modelling/Documents/SC53E9.pdf

International Whaling Commission (2001) Report of the workshop on the comprehensive assessment of right whales: a worldwide comparison. J Cetacean Res Manag 2(Spec Issue):1-35

International Whaling Commission (2004) Report of the subcommittee on other Southern Hemisphere whale stocks. J Cetacean Res Manag 6:246-271

International Whaling Commission (2005) Report of the subcommittee on other Southern Hemisphere whale stocks. J Cetacean Res Manag 7:235-246

International Whaling Commission (2006) Report of the subcommittee on other Southern Hemisphere whale stocks. J Cetacean Res Manag 8:151-170

International Whaling Commission (2007) Report of the subcommittee on other Southern Hemisphere whale stocks. J Cetacean Res Manag 9:188-209

International Whaling Commission (2010) Report of the joint CCAMLR-IWC workshop to review input data for Antarctic marine ecosystem models. J Cetacean Res Manag 11(Suppl 2): 541-586

International Whaling Commission (2011a) Report of the southern right whale die-off workshop. J Cetacean Res Manag 12(Suppl): 365-398

International Whaling Commission (2011b) Report of the sub-committee on other Southern Hemisphere whale stocks. J Cetacean Res Manag 12:203-226

Katona SK, Beard JA (1990) Population size, migrations and feeding aggregations of the humpback whale (Megaptera novaeangliae) in the western North Atlantic Ocean. Rep Int Whal Comm 12:295-305

Kemp S, Bennett AG (1932) On the distribution and movements of whales on the South Georgia and South Shetland whaling grounds. Disc Rep 6:165-190
Leaper R, Cooke J, Trathan P, Reid K, Rowntree V, Payne R (2006) Global climate drives southern right whale (Eubalaena australis) population dynamics. Biol Lett 2:289-292

Mackintosh NA, Wheeler JFG, Clowes A (1929) Southern blue and fin whales. Disc Rep 1:257-540

Moore MJ, Berrow SD, Jensen BA, Carr P and others (1999) Relative abundance of large whales around South Georgia (1979-1998). Mar Mamm Sci 15:1287-1302

Murphy EJ, Trathan PN, Watkins JL, Reid K and others (2007) Climatically driven fluctuations in Southern Ocean ecosystems. Proc R Soc Lond B 274:3057-3067

> Paterson R, Paterson P (1989) The status of the recovering stock of humpback whales Megaptera novaeangliae in East Australian waters. Biol Conserv 47:33-48

Payne R, Rowntree V, Perkins JS, Cooke JG, Lankester K (1990) Population size, trends and reproductive parameters of right whales (Eubalaena australis) off Peninsula Valdes, Argentina. Rep Int Whal Comm 12:271-278

Reid K, Brierley A, Nevitt G (2000) An initial examination of relationships between the distribution of whales and Antarctic krill Euphausia superba at South Georgia. J Cetacean Res Manag 2:143-149

Reilly S, Hedley S, Borberg J, Hewitt R, Thiele D, Watkins J, Naganobu M (2004) Biomass and energy transfer to baleen whales in the South Atlantic sector of the Southern Ocean. Deep-Sea Res II 51:1397-1409

Rossi-Santos MR, Baracho C, Cipolotti S, Marcovaldi E (2007) Cetacean sightings near South Georgia Islands, South Atlantic Ocean. Polar Biol 31:63-68

Rowntree VJ, Payne RS, Schell DM (2001) Changing patterns of habitat use by southern right whales (Eubalaena australis) on their nursery ground at Península Valdés, Argentina, and in their long-range movements. J Cetacean Res Manag 2:133-143

Širovic A, Hildebrand JA, Thiele D (2006) Baleen whale spatial patterns in the Scotia Sea during January and February 2003. J Cetacean Res Manag 8:161-171

Stevick P, De Godoy L, McOsker M, Engel M, Allen J (2006) A note on the movement of a humpback whale from Abrolhos Bank, Brazil to South Georgia. J Cetacean Res Manag 8:297-300

Tønnessen JN, Johnsen AO (1982) The history of modern whaling. University of California Press, Berkeley, CA

Tynan CT (1998) Ecological importance of the southern boundary of the Antarctic Circumpolar Current. Nature 392:708-710

Valenzuela LO, Sironi M, Rowntree VJ, Seger J (2009) Isotopic and genetic evidence for culturally inherited site fidelity to feeding grounds in southern right whales (Eubalaena australis). Mol Ecol 18:782-791

Williams R, Hedley SL, Hammond PS (2006) Modeling distribution and abundance of Antarctic baleen whales using ships of opportunity. Ecol Soc 11:1. www.ecology andsociety.org/vol11/iss1/art1/

> Zerbini AN, Andriolo A, Heide-Jørgensen MP, Pizzorno JL and others (2006) Satellite-monitored movements of humpback whales Megaptera novaeangliae in the Southwest Atlantic Ocean. Mar Ecol Prog Ser 313:295-304

Submitted: April 25, 2012; Accepted: October 12, 2012

Proofs received from author(s): December 3, 2012 